\title{
3D Printed Microwave Clamp Probe Design to Detect Water Level in PVC Pipes
}

\author{
Ömer KASAR ${ }^{1}$, Mahmut Ahmet Gözel ${ }^{2}$, Mustafa Geçin ${ }^{2}$ \\ ${ }^{1}$ Department of Electrical and Electronics Engineering, Artvin Çoruh University, Artvin, Turkey \\ ${ }^{2}$ Department of Electrical and Electronics Engineering, Süleyman Demirel University, Isparta, \\ Turkey
}

\begin{abstract}
The permittivity of water is considerably larger than that of air. As the amount of water in PVC water pipes increases, the air will be replaced by water. This means that the electromagnetic environment properties inside the pipe will change. In this study, we proposed a microwave clamp probe designed with a 3D printer that can detect the percentage of water in 50 mm diameter PVC water pipes. The clamp probe allows measurement of return loss from a single port for determining the fill rate of water without any physical intervention from outside the pipe. The clamp, which is structurally similar to a loop antenna, operates at a frequency of 2.45 $\mathrm{GHz}$. As a result of simulations and experimental measurements for different fill percentages of the pipe, the input impedance of the clamp was calculated. Then, an impedance-fill rate graph was created, showing the amount of water in the pipe section according to the impedance values obtained. The impedance seen from the clamp input indicated a linear increase between 40-100 $\Omega$, according to the $0 \%, 20 \%, 50 \%, 80 \%$ and $100 \%$ of the water in the pipe. The clamp has a compact structure that can be used as a plug-and-play anywhere on the horizontal.
\end{abstract}

Keywords: Microwave Clamp Probe; Impedance Analysis; PVC Water Pipe; Pipe Fill Rate; Loop Antenna Design

\section{D natisnjena zasnova mikrovalovne sonde za zaznavanje nivoja vode $v$ PVC ceveh}

Izvleček: Permisivnost vode je precej večja od permisivnosti zraka. Ko se količina vode v PVC vodovodnih ceveh poveča, zrak nadomesti voda. To pomeni, da se bodo spremenile lastnosti elektromagnetnega okolja $\vee$ cevi. $\vee$ tej študiji smo predlagali mikrovalovno sondo s kleščami, zasnovano s 3D-tiskalnikom, ki lahko zazna odstotek vode v vodovodnih ceveh iz PVC s premerom $50 \mathrm{~mm}$. Objemna sonda omogoča merjenje povratnih izgub iz ene same odprtine za določanje stopnje napolnjenosti z vodo brez fizičnega posega z zunanje strani cevi. Sponka, ki je strukturno podobna anteni z zanko, deluje pri frekvenci 2,45 GHz. Na podlagi simulacij in eksperimentalnih meritev za različne odstotke napolnjenosti cevi je bila izračunana vhodna impedanca objemke. Nato je bil izdelan graf impedance in stopnje napolnjenosti, ki prikazuje količino vode $v$ delu cevi glede na dobljene vrednosti impedance. Impedanca na vhodu klešč je pokazala linearno povečanje med 40 in $100 \Omega$ glede na 0\%, 20 \%, 50 \%, 80 \% in $100 \%$ vode v cevi. Sponka ima kompaktno strukturo, ki se lahko uporablja kot priključek „plug-and-play“ kjer koli na vodoravni površini.

Ključne besede: Mikrovalovna sonda s kleščami; impedančna analiza; PVC vodovodna cev; stopnja napolnjenosti cevi; zasnova antene z zanko

*Corresponding Author's e-mail:omerkasar@artvin.edu.tr

\section{Introduction}

There are several ways to measure the amount of water in a polyvinyl chloride (PVC) water pipe without visual and physical contact. The technique proposed in this study is based on the "Microwave Measurement Method". In terms of electromagnetic waves to penetrate objects, microwave circuits can provide the more sensitivity than low frequency basic electronic circuits cannot reach.

\section{How to cite:}

Ö. Kasar et al., "3D Printed Microwave Clamp Probe Design to Detect Water Level in PVC Pipes", Inf. Midem-J. Microelectron. Electron. Compon. Mater., Vol. 51, No. 3(2021), pp. 151-155 
The distilled water has high permittivity at the microwave frequencies. By the means of this feature, water level detection in a PVC pipe is possible using microwave circuits. The permittivity of distilled water is about 80 times higher than air. This means that the level of the distilled water will change the electromagnetic properties of the medium inside the pipe. By selecting a suitable frequency, different input impedances can be determined by changing this water-air ratio.

There are very few studies in the literature that aim to determine the amount of water from the outside. They generally reported attenuation in amplitude according to the change in the level of water by designing a kind of power transceiver system by placing an antenna on both sides of the water pipe [1]. In some studies, electro-acoustic circuit methods and capacitive sensor applications have been used [2-7]. In a further application, computational estimation methods with radio frequency circuits were used to determine the amount of different liquids in the plastic water pipe [8]. Few studies such as these shows that methods that can measure the amount of water in PVC pipes with microwave circuits are open to development.

In this study, a clamp near field probe was designed. The amount of water in the pipe was tried to be determined by measuring from outside without any physical intervention to a PVC water pipe of known dimensions. Return Loss $(\mathrm{RL})$ obtained from the input of the clamp probe was determined according to the percentage change of water in the pipe. Then, impedance parameters were analyzed.

In the second part of the study, the 3D design of the clamp probe and the calculation of the fullness ratio were mentioned. In the third section, RL-frequency and impedance-frequency analyzes were performed according to the change in the amount of water in the pipe. Simulation and measurement results were compared. In the last section, the importance and originality of the study was emphasized.

\section{Microwave clamp probe design}

The designed microwave near field probe is in the form of a clamp that will surround the pipe when installed. The edges of the clamp, which can be opened to both sides with the help of a hinge, overlap when the hinge is closed. Thus, discontinuity will not occur circularly. The clamp is similar to a loop antenna whose ground part is outside the probe and the antenna part is also inside. An SMA connector was connected to one side of the clamp to be measured RL.
The clamp was designed for PVC water pipe with 50 $\mathrm{mm}$ outer diameter. The inner radius of the clamp is $R_{\text {in }}=26 \mathrm{~mm}$ and the outer radius is $R_{\text {out }}=38 \mathrm{~mm}$. Ground and antenna consist of $t=0.1 \mathrm{~mm}$ thick copper strip. The width of the clamp is $W_{2}=17 \mathrm{~mm}$ and the width of the antenna is $W_{\text {probe }}=5$. The lengths of the hinge are $W_{1}=30 \mathrm{~mm}$ and $L_{1}=20 \mathrm{~mm}$. The heights of the clamp are $L_{2}=93.5 \mathrm{~mm}$ and $L_{3}=76 \mathrm{~mm}$. Figure $1 \mathrm{a}$ shows the design parameters of the clamp.

The clamp was designed in CST MWS program and fabricated in 3D printer. In additive manufacturing for microwave circuits, fill density is a critical parameter in determining substrate dielectric coefficient. Here the density was selected as $90 \%$. Thus, according to [1], the permittivity is $\epsilon_{\text {clamp }}=2.7$ and tangential loss is $\tan \delta=$ 0.008 . The design and manufacturing of the clamp was given in Figure $1 \mathrm{~b}$.

a)

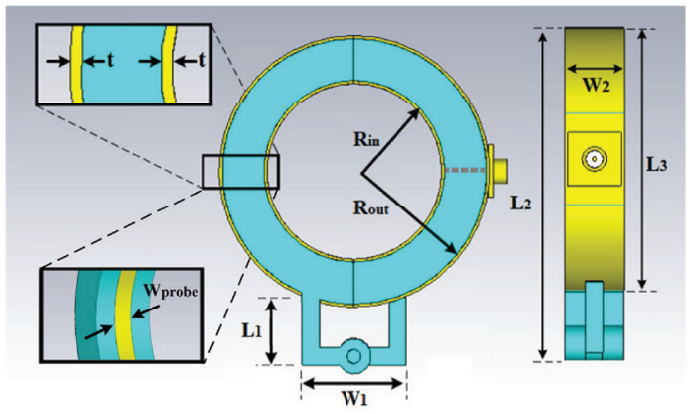

b)

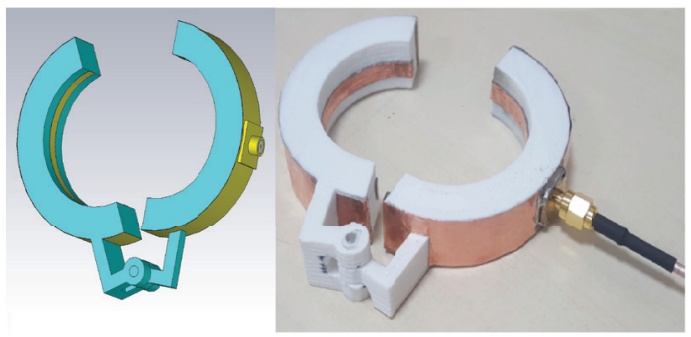

Figure 1: a) Dimensions of Clamp Probe b) Design and Manufactured View of the Clamp Probe.

The height of the water in the pipe, whose outer radius is $R_{p}=25 \mathrm{~mm}$ and the inner radius, is $R_{w}=23 \mathrm{~mm}$ and the dielectric coefficie is $\epsilon_{P V C}=2.8$ increases nonlinearly with respect to the water fill percentage. In the simulation, "cylindrical tank filling problem" was used to calculate the water height over the cross-sectional area [9]. The area covered by the water was calculated according to Equation (1).

$$
A=R_{w}{ }^{2} \cos ^{-1}\left(\frac{R_{w}-h}{R_{w}}\right)-\left(R_{w}-h\right) \sqrt{2 R_{w} h-h^{2}}
$$

where, $A$ is the cross-sectional area of the water in the pipe, $R_{w}$ is the inner radius of the pipe, and $h$ is the 
height of the water in the pipe. According to $10 \%$ changes of $A$, the water height was given in Table 1.

Table 1: The water height according to fill ratio in pipe.

\begin{tabular}{|c|c|c|c|}
$\begin{array}{c}\text { Fill ratio } \\
(\%)\end{array}$ & $\begin{array}{c}\text { Height } \\
(\mathrm{mm})\end{array}$ & $\begin{array}{c}\text { Fill Ratio } \\
(\%)\end{array}$ & $\begin{array}{c}\text { Height } \\
(\mathrm{mm})\end{array}$ \\
\hline 10 & 7.16 & 60 & 26.59 \\
\hline 20 & 11.67 & 70 & 30.33 \\
\hline 30 & 15.60 & 80 & 34.92 \\
\hline 40 & 19.40 & 90 & 38.83 \\
\hline 50 & 23 & 100 & 46 \\
\hline
\end{tabular}

The most decisive parameter for measuring the amount of water in the pipe using a single port clamp is the permittivity $\left(\epsilon_{\text {water }}=79.4\right)$. As the amount of water increases, the air in the pipe $\left(\epsilon_{\text {air }}=1\right)$ will be replaced by water. According to this displacement, the RL $\left(S_{11}\right)$ seen from the connector of the clamp will increase or decrease. Therefore, the impedance seen from the input will also change. In Figure 2, it is seen that the clamp was applied to the PVC pipe and the water change was measured with Rohde Schwarz FSH6 Spectrum (network) analyzer. In order for the spectrum analyzer to perform network analysis, the device must have a tracking generator. The reflected power must be transferred to the device input with directional coupler. Thus, the RL measurement can be made from the spectrum analyzer.

\section{Simulations and experimental results}

The clamp was designed for the frequency of $f_{0}=2.45 \mathrm{GHz}$ where it provides the inequality of $\left|S_{11}\right|<-10 \mathrm{~dB}$ [10]. RL vs. frequency graph of the clamp was shown in Figure 3a. Also in Figure 3b, measured according to the change in the percentage of water in the pipe, $\left|S_{11}\right|$ graph is given.

As seen in Figure $3 \mathrm{~b}$, magnitude of $S_{11}$ for the clamp could not provide high selectivity in determining the amount of water in the pipe [11]. The complex $S_{11}$ has been trans- a)

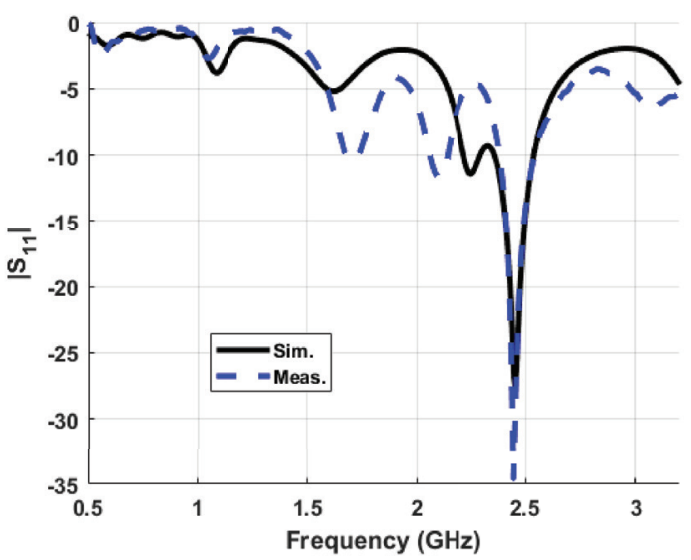

b)

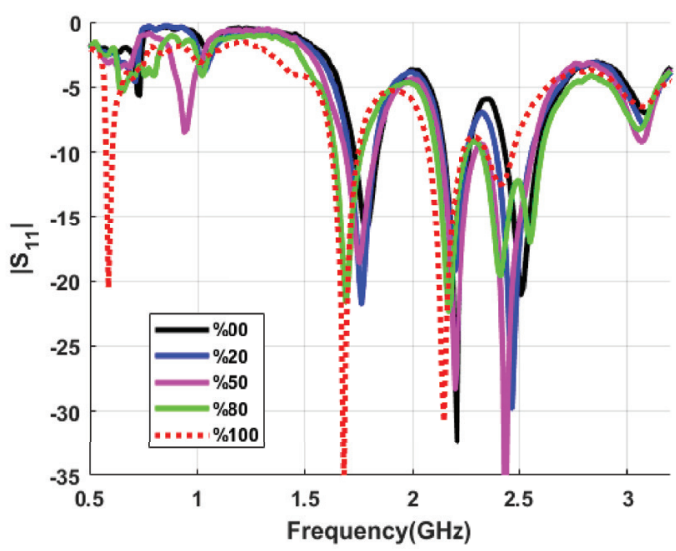

Figure 3: a) Return Loss of the clamp b) Return Loss according to amount of the water in pipe.

formed to impedance $\left(S_{11}\right)$ parameter according to Equation (2). Thus, significant range can be achieved between the impedance values of the pipe in different percentages.

$Z_{11}=Z_{0} \times \frac{\left(1+S_{11}\right)}{\left(1-S_{11}\right)}$

Since the probe is designed according to $Z_{0}=50+j 0$ $\Omega$ on the frequency $f_{0}$, the impedance magnitude $\left(\left|S_{11}\right|\right)$ was calculated according to Equation (3).
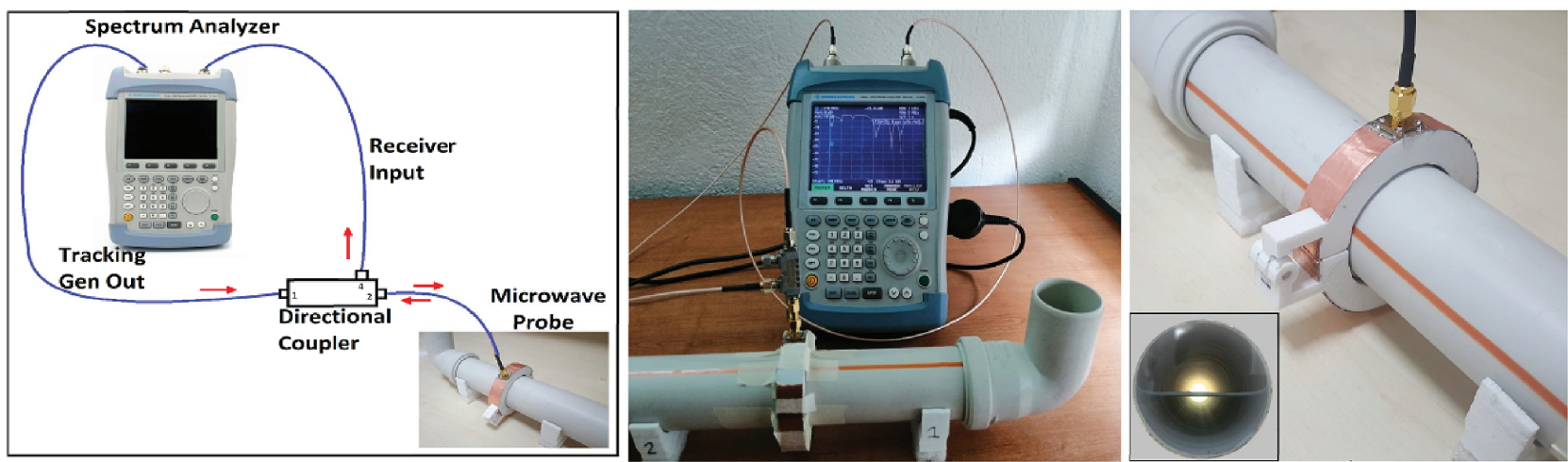

Figure 2: Application of probe to PVC pipe and measurement of water change. 


$$
\left|Z_{11}\right|=\sqrt{\left(\left(Z_{11}\right)_{\text {real }}\right)^{2}+\left(\left(Z_{11}\right)_{\text {complex }}\right)^{2}}
$$

In impedance calculation at $f_{0^{\prime}}$ simulation and measurement values were close to $Z_{0}$. In Figures $5 \mathrm{a}$ and $5 \mathrm{~b}$, it is seen that the magnitude of the $\left|S_{11}\right|$ changes according to different fullness percentages of the pipe. The intermediate occupancy percentages not shown here were not included in the graphic because they were very close to other values. The clamp provides linearity only for certain percentages given. The points marked on Figures $4 \mathrm{a}$ and $4 \mathrm{~b}$ are at $F_{\text {sim }}=f_{\text {meas }}=2.442 \mathrm{GHz}$ frequency at which the clamp operates.

a)

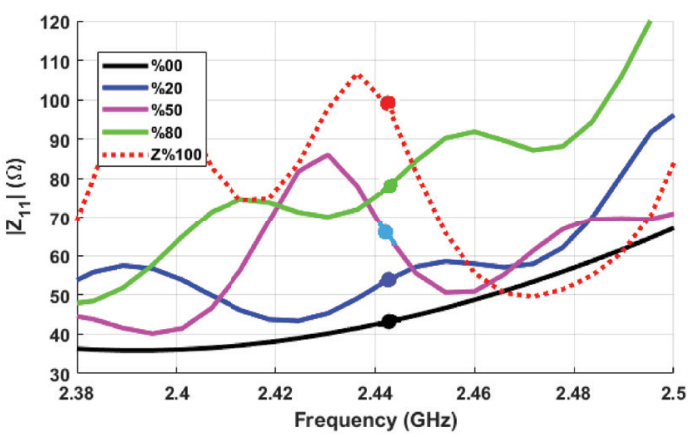

b)

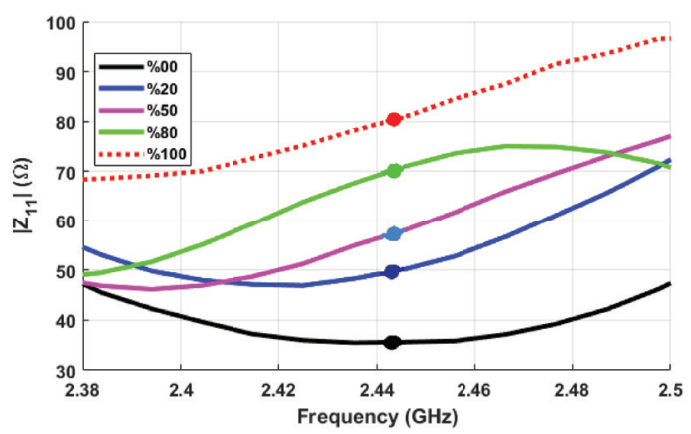

Figure 4: $\left|Z_{11}\right|$ vs. frequency graph for simulation (a) and measurement (b).

The measurement and simulation results were combined in Figure 4 which is the graph of the impedance magnitude vs. fill ratio. As shown in the figure, when

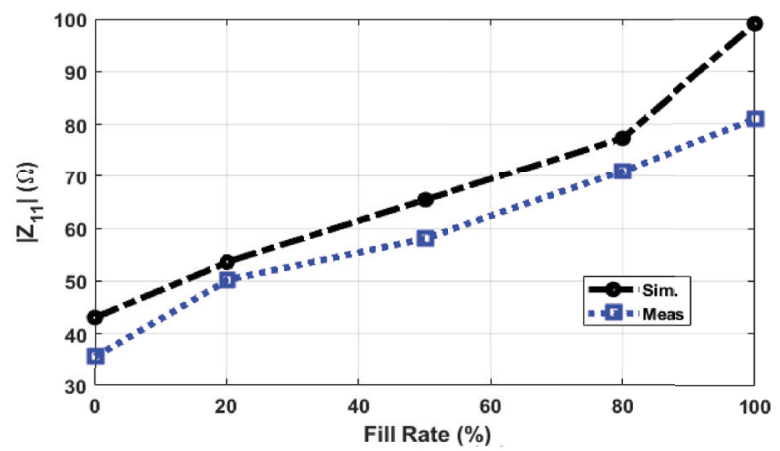

Figure 5: The graph of impedance vs fill ratio. the occupancy rate is increased from $0 \%$ to $100 \%,\left|Z_{11}\right|$ also increases linearly. The fact that the simulation and measurement were compatible with each other supports this. The minor impedance difference between them consists of connector and path losses in the measurement.

\section{Conclusion}

In this study, a near field probe was designed using a 3D printer to determine the amount of water in PVC water pipes. Thanks to the clamp-shaped design of the probe, measurements can be made from outside the pipe without any physical intervention to the pipe. The amount of water in the pipe can be determined without visual contact with the water in the pipe.

The clamp resembles a loop antenna, the ground of which is outside the probe, and the antenna is inside. In determining the filling rate of the water in the pipe, the input impedance was calculated by measuring the return loss.

By making use of the permittivity of the water approximately 80 times more than that of the air, an impedance graph was created according to the filling rate of the water in the pipe. Thus, the amount of water in the pipe can be determined according to the impedance value obtained from the measurement. The clamp exhibits linear impedance increase between 40-100 $\Omega$ at $0 \%, 20 \%, 50 \%, 80 \%$ and $100 \%$ occupancy of the water in the pipe. Measurement and simulation results are very close to each other. The clamp is compact in such a way that it can be used anywhere in the pipe as plugand-play. The proposed original clamp probe design can also be developed for pipes of different types and thicknesses.

\section{Acknowledgement}

This work was supported by Artvin Çoruh University Scientific Research Projects Coordinator (BAP). Funding Number is 2019.F14.02.01

\section{Conflict of interest}

No conflict of interest has been declared by the authors. 


\section{References}

1. H. E. de Lima Ávila, D. J. Pagano, and F. R. de Sousa, "Improving the performance of an RF resonant cavity water-cut meter using an impedance matching network," Flow Measurement and Instrumentation, vol. 43, pp. 14-22, 2015. https://doi.org/10.1016/j.flowmeasinst.2015.02.002

2. H. Truong et al., "Capband: Battery-free successive capacitance sensing wristband for hand gesture recognition," in Proceedings of the 16th ACM Conference on Embedded Networked Sensor Systems, 2018, pp. 54-67. https://doi.org/0.1145/3274783.3274854)

3. R. Dell' Acqua, "Sensors: A Great Chance for Microelectronic Technologies", Informacije MIDEM, 24 (1994) 4, Ljubljana (http://www.midem-drustvo.si/ Journal\%20papers/MIDEM_24(1994)4p248.pdf)

4. Kasar, Ö. (2020). "Determining The Water Level in Pvc Water Pipes With Micro-Strip Dipole Antennas." Mühendislik Bilimleri ve Tasarım Dergisi, 8(4), 1165-1169.

https://doi.org/10.21923/jesd.807389

5. Kasar, Ö, Geçin, M, Gözel, MA. Design and implementation of a 3D printed RF power transceiver clamp to measure the water level in PVC water pipes. Int J RF Microw Comput Aided Eng. 2021; 31:e22644.

https://doi.org/10.1002/mmce.22644

6. F. R. M. da Mota, D. J. Pagano, and M. E. Stasiak, "Water volume fraction estimation in two-phase flow based on electrical capacitance tomometry," IEEE Sensors Journal, vol. 18, no. 16, pp. 6822-6835, 2018. https://doi.org/10.1109/JSEN.2018.2849684

7. M. Tayyab, M. S. Sharawi, and A. Al-Sarkhi, "A radio frequency sensor array for dielectric constant estimation of multiphase oil flow in pipelines," IEEE Sensors Journal, vol. 17, no. 18, pp. 5900-5907, 2017. https://doi.org/10.1109/JSEN.2017.2732164

8. S. Zhang, C. C. Njoku, W. G. Whittow, and J. C. Vardaxoglou, "Novel 3D printed synthetic dielectric substrates," Microwave and Optical Technology Letters, vol. 57, no. 10, pp. 2344-2346, 2015. https://doi.org/10.1002/mop.29324
9. E. W. Weisstein. "Quarter-Tank Problem." https:// mathworld.wolfram.com/Quarter-TankProblem. html (accessed 19.04.2020).

10 C. A. Balanis, Antenna theory, analysis and design, 3rd ed. New York, USA: Wiley, 2005. (ISBN: 978605-133-617-6)

11. D. M. Pozar, Microwave Engineering, 3rd ed. New York, USA: Wiley, 2006. (ISBN: 978-0-470-63755-3)

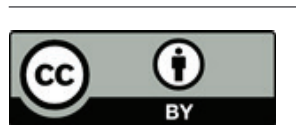

Copyright $\odot 2021$ by the Authors. This is an open access article distributed under the Creative Commons Attribution (CC BY) License (https://creativecommons.org/licenses/by/4.0/), which permits unrestricted use, distribution, and reproduction in any medium, provided the original work is properly cited.

Arrived: 01. 01. 2021

Accepted: 27.07. 2021 